\title{
Comparison of Membrane Filtration and Replica Plate Technique to Detect Fecal Coliform
}

\author{
Bikram Gautam ${ }^{1,2}$ and Rameshwar Adhikari²
}

${ }^{1}$ Department of Microbiology, St. Xavier's College, Maitighar, Kathmandu, Nepal

${ }^{2}$ Research Centre for Applied Science and Technology (RECAST), Tribhuvan University, Kirtipur, Kathmandu, Nepal

\section{ABSTRACT}

Introduction: Membrane filtration (MF) is one of the widely used technique on a routine basis. On the other hand, replica plate (RP) technique can be used to transfer existing bacterial colonies in 2 plates which even allows pinpointing the original colony. The aim of this study is to comparatively detect the cfu/100 mL of fecal coliform using MF and RP techniques.

Methods: In the study, a total of 25 bottled water were selected from the local market in Kathmandu valley. The total coliform count was detected using MF, while fecal coliform was detected using both MF and RP technique.

Results: It was found that the average cfu/100 mL for total coliform, fecal coliform (MF) and fecal coliform (RP) were 143.38, 49.82, 51.00 respectively. Pearson correlation coefficient calculated between total coliform and fecal coliform (MF), total coliform and fecal coliform (RP), fecal coliform (MF) and fecal coliform (RP) were found to be $0.695,0.733$ and 0.990 respectively; implying a positive correlation.

Conclusions: It has been demonstrated that intrinsic and extrinsic factors influence colony forming units. Furthermore, RP is a more sensitive method for screening fecal coliforms although both MF and RP can be efficiently used.

Keywords: cfu/100 mL; fecal coliform; MF technique; RP technique; total coliform

Correspondence: Bikram Gautam, Department of Microbiology, St. Xavier's College, Maitighar, Kathmandu, Nepal and Research Center for Applied Science and Technology (RECAST), Tribhuvan University, Kathmandu, Nepal. Email: gautambikr@gmail.com

DOI: http://dx.doi.org/10.3126/mjsbh.v17i2.19327

Submitted on: 2018-03-06

Accepted on: 2018-06-25 


\section{INTRODUCTION}

It has long been debated on which method for detecting fecal coliform is the best and precise one. As there are many tests available for detection of fecal coliform but the most preferred ones are most probable number and membrane filtration technique. Membrane filtration (MF) technique is one of the tests that is routinely practiced test laboratories which involves filtration to trap microbes (such as bacteria, fungi, molds etc) in the cellulose membrane.1,2 Replica plate (RP) technique isn't popular which could be due to ease in the methodology of membrane filtration and most probable number technique; labor and material intensive methodology of replica plate; technical expertise in obtaining, interpreting and confirming results of replica plate. ${ }^{3,4}$

RP technique allows comparison of colony pattern on 2 plates ( $1^{\text {st }}$ and $2^{\text {nd }}$ ), by allowing a convenient method to screen all the colonies and detect a desired phenotype/characteristic of the colony. ${ }^{4}$ The RP technique can also help in the screening of acquired antibiotic resistance, 5 small colony variants 6,7 present in original colonies of the $1^{\text {st }}$ plate.

Variability in MF and RP technique result analysis can be due to intrinsic factors (such as procedure design, natural dispersion of bacteria within the bottle etc) and extrinsic factors (like lack of resources and materials hence deviating from expected methodology, clumping of bacterial cells, reduction in microbial number caused by cell damage caused by vacuum's pressure, environmental conditions at the time of sampling, turbidity, and season etc). ${ }^{1,8,9}$ Nobel et al. (2003) acknowledged that different test procedures ${ }^{1,8}$ are likely to yield different fecal coliform number which could be due to a variety of intrinsic and extrinsic factors (including the difference in metabolic process endpoints).
Scientists across the globe are struggling to pinpoint the colonies which have acquired changes (ie mutated) over the period of time. As the pinpoint of correct colonies could reveal a pattern of mutation. The major causes of mutation are genetic jugglery, transposons, the lysogenic cycle of bacteriophage, plasmid incorporation etc. This study focuses on detecting a number of colony forming unit both in membrane filtration and replica plate technique. This data will provide knowledge on which method for detecting is best and precise.

The aim of this study is to detect $\mathrm{cfu} / 100 \mathrm{~mL}$ of fecal coliform using MF and RP technique.

\section{METHODS}

The study was performed in Department of Microbiology, St. Xavier's College, Maitighar. The study was conducted from June 2017 to September 2017. A total of 25 bottled water locally available in Kathmandu valley was selected based on their availability. A bottled water of $20 \mathrm{~L}$ was purchased in the market. After shaking the bottle, the seal was opened in the market/retailer and the neck was sterilised with $70 \%$ ethanol. Four sterilised bottles were filled leaving headspace and were labeled properly. The collected samples were kept in a mini cooler with ice packs and transported to the laboratory to be processed.

Coliform count by MF technique:

i. Sterile M-endo agar: Sterile prepared M-endo agar was taken out of the refrigerator and was dried in hot air oven at $55^{\circ} \mathrm{C}$ for 5 minutes.

ii. Filtration of water sample: Inside aseptic conditions, membrane filtration apparatus was set and was disinfected with $70 \%$ alcohol. 100 $\mathrm{mL}$ water sample was filtered through the membrane (cellulose) filter of pore size $0.45 \mu \mathrm{m}$. With the help of sterile forceps, the filter paper was transferred to M-endo agar. 
iii. Total coliform screening: The M-endo agar from process "ii." was marked and was incubated at $37^{\circ} \mathrm{C}$ for 24 hours..$^{10,11}$

iv. Fecal coliform screening: Process "ii." was repeated. The M-endo agar was incubated at $44.5^{\circ} \mathrm{C}$ for 24 hours..$^{10}$

v. Repetition and quality control: Step "ii.", "iii." and "iv." were triplicated and repeated for all the samples. Step "iii." and "iv." were repeated such that the filter paper (without filtered i.e. direct from the sealed sachet) were placed on the agar surface. The plates were incubated at $37^{\circ} \mathrm{C}$ and $44.5^{\circ} \mathrm{C}$ for 24 hours respectively. Presence of colonies was looked upon the incubated plates. ${ }^{12}$

vi. Calculation: The result was expressed as a number of cfu/100 mL of water ${ }^{9}$. Cfu/100 mL from process "iii." and "iv." was detected as: total colonies counted.

Colony count by RP technique:

i. Primary plate: The plate with the filtered paper incubated at $37^{\circ} \mathrm{C}$ for 24 hours was marked (with orientation) and taken as a primary plate.

ii. Sterilisation of cylindrical block, clamp and velveteen cloth: The wooden block, clamp and velveteen cloth were wrapped in aluminum foil and then placed in an autoclave at $121^{\circ} \mathrm{C}$ at $15 \mathrm{lbs}$ for 15 minutes. The cylindrical block, clamp and velveteen cloth were taken out from the autoclave with the foil intact and was then dried in a hot air oven.

iii. Transfer of colonies from primary plate to secondary plate: In sterile condition, sterile velveteen cloth was placed over the cylindrical block and was locked with the help of the clamps. The cylindrical block covered with velveteen cloth was lowered to the surface of the agar so that there was contact between velveteen plate and the colonies on the agar surface. The cylindrical block covered with velveteen cloth was then lowered to the secondary plate (M-endo) so that the impressions of the cells in the velveteen plates were inoculated in the secondary plate. The plate was marked (with orientation) again and was incubated at $44.5^{\circ} \mathrm{C}$ for 24 hours. ${ }^{12}$

iv. Repetition and quality control: Step "iii." was triplicated and was repeated for all the samples. Step "iii." was repeated in an agar medium devoid of colonies and was transferred to secondary plate.3,4,12 The observed colonies were counted, which was cfu/100 $\mathrm{mL}$ (as the initial filtrated water sample was $100 \mathrm{~mL}$ in volume).

The statistical calculation was done using SPSS version 19.

\section{RESULTS}

In a total of 25 bottled water samples, 24 were contaminated with coliform while 1 sample was devoid of contamination of coliform. In the 24 contaminated samples, coliform count detected through MF technique revealed that $\mathrm{cfu} / 100 \mathrm{~mL}$ ranged from 3 - Too Many To Count (TMTC) $(\mathrm{M}=143.38, \mathrm{SD}=132.8) \mathrm{cfu} / 100 \mathrm{~mL}$. These results are presented in Table 1, represented in Figure 1 and shown in Figure $(2,5)$.

Table 1. Comparison of $\mathrm{Cfu} / \mathbf{1 0 0} \mathrm{mL}$ count of total coliform and fecal coliform (both MF and RP)

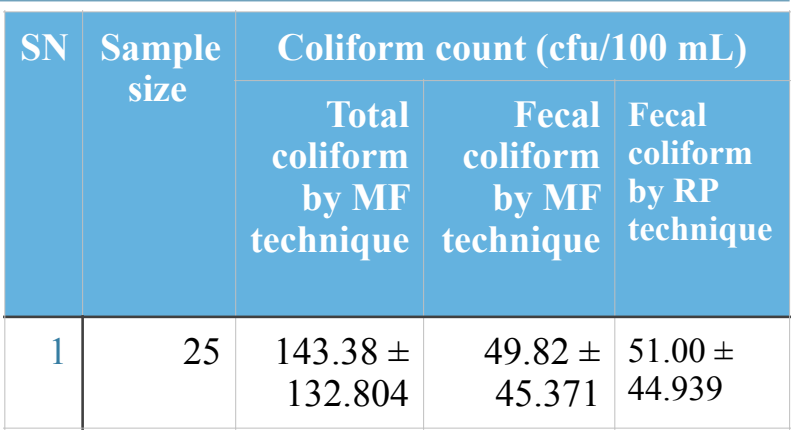




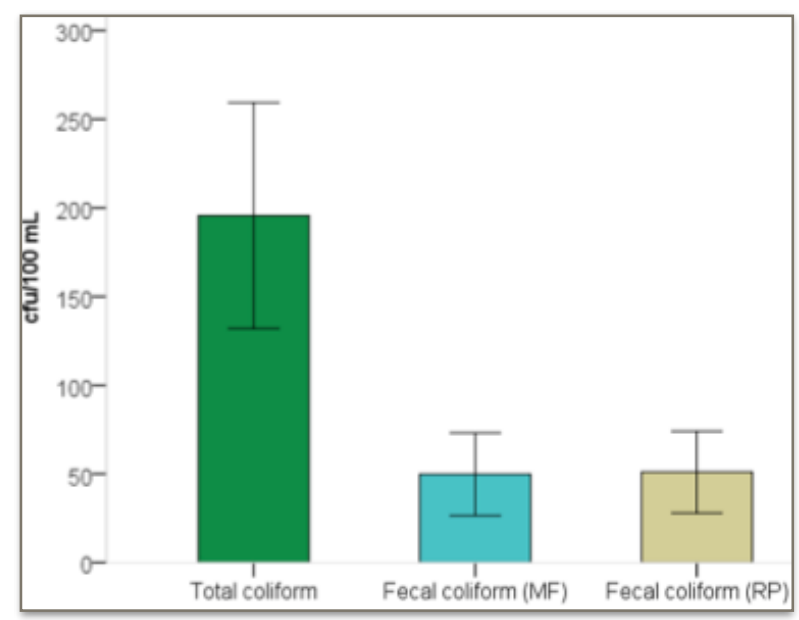

Fig 1. Wick and candle diagram illustrating coliform count vs efu/100 mL

The MF and RP technique revealed that 17 samples were contaminated with fecal coliform and eight samples were free from contamination with fecal coliform. In the 17 contaminated samples, fecal coliform detected through MF technique revealed that $\mathrm{cfu} / 100 \mathrm{~mL}$ ranged from no viable count -163 $(\mathrm{M}=49.82, \mathrm{SD}=45.37) \mathrm{cfu} / 100 \mathrm{~mL}$. In the 17

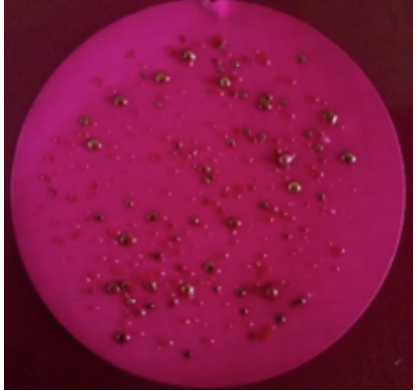

Fig 2. Total coliform (MF) count (cfu/100 mL) of sample $\mathrm{Zxc}_{4}$

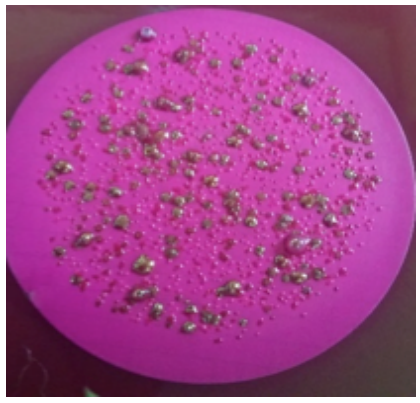

Fig 5. Total coliform (MF) count (cfu/100 $\mathrm{mL})$ of sample $\mathrm{Zxc}_{14}$

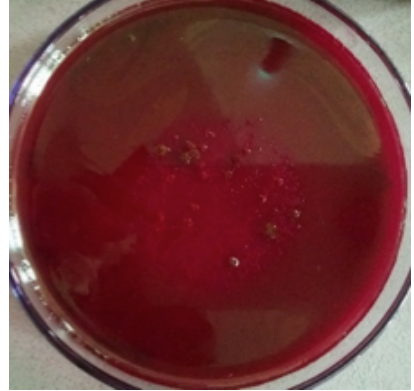

Fig 3. Fecal coliform (RP) count (cfu/100 mL) of sample $\mathrm{Zxc}_{4}$

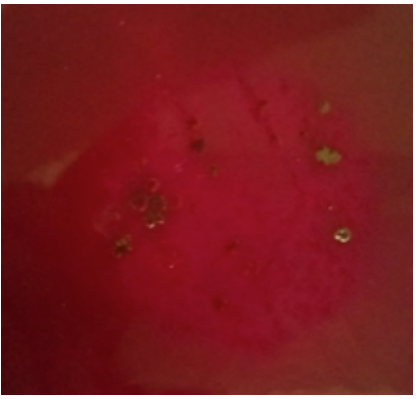

Fig 6. Fecal coliform (RP) count (cfu/100 mL) of sample $\mathrm{Zxc}_{14}$

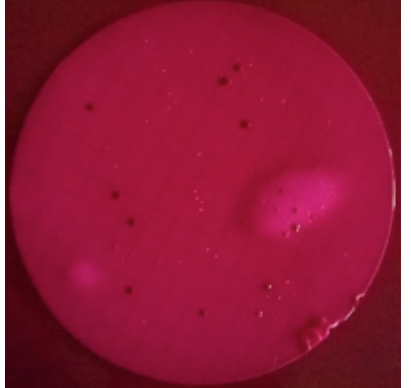

Fig 4. Fecal coliform (MF) count $(\mathrm{cfu} / 100 \mathrm{~mL})$ of sample $\mathrm{Zxc}_{4}$

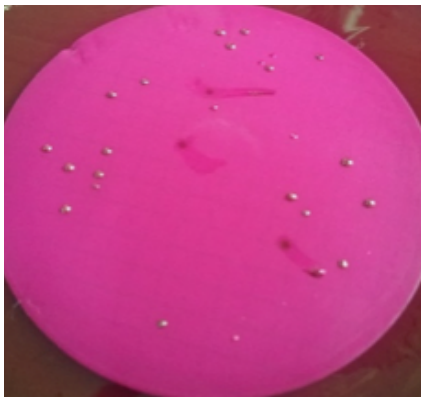

Fig 7. Fecal coliform (MF) count (cfu/100 mL) of sample $\mathrm{Zxc}_{14}$ 
Table 2: Results from comparison between three different coliform's results as per Pearson's correlation coefficient

\begin{tabular}{|c|c|c|c|c|c|c|c|}
\hline SN & $\begin{array}{c}\mathrm{N} \\
\text { (total } \\
\text { sample size) }\end{array}$ & & $\begin{array}{l}\text { Total } \\
\text { coliform }\end{array}$ & $\begin{array}{l}\text { Fecal } \\
\text { coliform } \\
(\mathrm{MF})\end{array}$ & $\begin{array}{l}\text { Fecal } \\
\text { coliform } \\
\text { (RP) }\end{array}$ & $\begin{array}{l}\text { Significance } \\
\text { level }\end{array}$ & Inference \\
\hline 1 & 25 & $\begin{array}{l}\text { Total } \\
\text { coliform }\end{array}$ & 1 & & & 0.01 & - \\
\hline 2 & & $\begin{array}{l}\text { Fecal } \\
\text { coliform } \\
(\mathrm{MF})\end{array}$ & 0.695 & 1 & & & $\begin{array}{l}\text { Positive correlation } \\
\text { between total coliform and } \\
\text { fecal coliform (MF) }\end{array}$ \\
\hline 3 & & $\begin{array}{l}\text { Fecal } \\
\text { coliform } \\
\text { (RP) }\end{array}$ & 0.733 & 0.990 & 1 & & $\begin{array}{l}\text { Positive correlation } \\
\text { between total coliform and } \\
\text { fecal coliform (RP), and } \\
\text { fecal coliform (RP) and } \\
\text { fecal coliform (MF) } \\
\text { respectively }\end{array}$ \\
\hline
\end{tabular}

technique) were 143, 50, 51 (Table 1, Figure 1, 2-7). The Pearson's correlation coefficient between $\mathrm{cfu} / 100 \mathrm{~mL}$ of the total coliform and fecal coliform (MF technique), total coliform and fecal coliform (RP technique), fecal coliform (MF technique) and fecal coliform (RP technique) are $0.695,0.733$ and 0.990 respectively; which implies positive correlation (Table 2).

The Pearson's correlation coefficient is significantly less (i.e. 0.695 ) than other two values (i.e. 0.733 and 0.990) suggesting that the relationship between total coliform and fecal coliform (MF) is, in fact, dependent on bacterial load in the bottled water. The less value (i.e. 0.695) can also be explained by the fact that that the bacterial load in the bottled water might not have been due to intrinsic factors and extrinsic factors. $1,8,9$

The Pearson's correlation coefficient is significantly moderate (i.e. 0.733 ) than other two values (i.e. 0.695 and 0.990 ) indicating that the relationship between total coliform and fecal coliform (RP) is, in fact, dependent on bacterial load in the colonies on the $1^{\text {st }}$ plate which could have small colony variants. ${ }^{6,7}$ The value (i.e. 0.733 ) can also be explained by the fact that that the bacterial load transferred in the $2^{\text {nd }}$ plate might be influenced by labor-intensive methodology; technical expertise in analysing and evaluating the results of the replica plate. 3,4

The Pearson's correlation coefficient is significantly high (i.e. 0.990) than other two values (i.e. 0.733 and 0.695 ) highlighting the fact that the relationship between fecal coliform (MF) and fecal coliform (RP) is, in fact, dependent on bacterial load in both, the bottled water and colonies in $1^{\text {st }}$ plate respectively. The value (i.e. 0.990) can also be explained by the fact that fecal coliform was screened (Table 1, Figure 1, 3, 4, 6, 7). The findings of this study suggest that, although different methods were selected the statistical error seems small, in case of the relationship between fecal coliform (MF) and fecal coliform (RP). Due to lack of prior studies on this topic the findings of this study could not be compared with.

Both RP and MF technique is susceptible to clumping, as observed colonies are transferred in former and $100 \mathrm{~mL}$ water is filtered through the apparatus in the later, which might aid in clumping of the bacteria respectively. ${ }^{1,8,9}$ The reason could be 
the capacity to form biofilms by the coliform. ${ }^{13}$ To detect fecal coliform from total coliform, replica plate method was chosen as it is the only procedure which enables transportation of entire colonies in a go. 3,4 The microorganisms could be uniformly distributed in the bottled water by shaking up to 25 times. ${ }^{1}$

This study is among the first to compare the two methodologies to quantify $\mathrm{cfu} / 100 \mathrm{~mL}$ between the MF and RP for fecal coliform. The findings of the study suggest that RP technique is sensitive, acceptable and can be used in the laboratory for routine analysis/screening, which will be more economical than MF. RP can be used to screen multi drug-resistant pathogens in a go too, saving both time and expenses.

\section{CONCLUSIONS}

Replica plate technique (as all colonies are transferred from the $1^{\text {st }}$ plate) is more sensitive than membrane filtration technique (due to intrinsic and extrinsic factors).
Both membrane filtration method and replica plate method can be used to detect fecal coliform as the correlation between the total coliform and fecal coliform (MF technique), total coliform and fecal coliform (RP technique) were significantly respectively.

Membrane filter can be used to screen the etiological agent causing outbreaks while replica plate method can be used to screen mutated colonies from the original colonies.

\section{ACKNOWLEDGMENT}

Special thanks go to Mr. Sudhakar Pant, Head of Department, Department of Microbiology, St. Xavier's College, Maitighar. We are also indebted to our scientific advisors Mr. Kanchan Thapa and Mr. Raja Ram Gurung. We are thankful for the suggestions given by Mr. Gopi Neupane and Mrs. Jeena Amatya.

To cite this article: Gautam B, Adhikari R. Comparison of membrane filtration and replica plate technique to detect fecal Coliform. MJSBH. 2018;17(2):25-31.

Conflict of Interest: None declared

\section{REFERENCES}

1. Noble RT, Weisberg SB, Leecaster MK, McGee CD, Ritter K, Walker KO, et al. Comparison of beach bacterial water quality indicator measurement methods. Environmental Monitoring and Assessment. 2003;81(1-3):301-12.

DOI: https://doi.org/10.1023/A:1021397529041

2. Buckalew D, Hartman L, Grimsley G, Martin A, Register K. A long-term study comparing membrane filtration with Colilert ${ }^{\circledR}$ defined substrates in detecting fecal coliforms and Escherichia coli in natural waters. Journal of Environmental Management. 2006;80(3):191-7.

DOI: https://doi.org/10.1016/j.jenvman.2005.08.024

3. Gibbs SG, Green CF, Tarwater PM, Mota LC, Mena KD, Scarpino PV. Isolation of antibiotic-resistant bacteria from the air plume downwind of a swine confined or concentrated animal feeding operation. Environmental Health Perspectives. 2006;114(7):1032. 
DOI: https://dx.doi.org/10.1289\%2Fehp.8910

4. Sanders ER. Aseptic laboratory techniques: plating methods. Journal of visualized experiments: JoVE. 2012(63).

DOI: $10.3791 / 3064$

5. Kohanski MA, DePristo MA, Collins JJ. Sublethal antibiotic treatment leads to multidrug resistance via radical-induced mutagenesis. Molecular cell. 2010;37(3):311-20.

DOI: https://doi.org/10.1016/j.molcel.2010.01.003

6. Proctor RA, Von Eiff C, Kahl BC, Becker K, McNamara P, Herrmann M, et al. Small colony variants: a pathogenic form of bacteria that facilitates persistent and recurrent infections. Nature Reviews Microbiology. 2006;4(4):295.

DOI: $10.1038 /$ nrmicro1384

7. Häußler S, Ziegler I, Löttel A, Götz Fv, Rohde M, Wehmhöhner D, et al. Highly adherent small-colony variants of Pseudomonas aeruginosa in cystic fibrosis lung infection. Journal of medical microbiology. 2003;52(4):295-301.

DOI: $10.1099 / \mathrm{jmm} \cdot 0.05069-0$

8. Kloot RW, Radakovich B, Huang X, Brantley DD. A comparison of bacterial indicators and methods in rural surface waters. Environmental monitoring and assessment. 2006;121(1-3):275-87.

DOI: https://doi.org/10.1007/s10661-005-9121-5

9. APHA. Standard Methods for the Examination of Water and Wastewater. 21 ed. Washington DC: American Public Health Association; 2005.

10. Gautam B, Dongol E, Shrestha A. In-vitro antimicrobial activity of different toothpastes. Journal of Kathmandu Medical College. 2017; 13(20): 52 - 8.

DOI: http://dx.doi.org/10.3126/jkmc.v6i2.19803

11. Gautam B, Pokhrel S, Aryal S et al. Efficacy of toothpaste in reducing micro-flora isolated from toothbrush. Kathmandu University Journal of Science, Engineering and Technology 2017; 13(2): 71 - 8.

12. Gautam B, Aryal L, Adhikari S et al. Isolation of bacteriophage from Guheswori sewage treatment plant capable of infecting pathogens. Research in Pharmacy and Health Sciences. 2018; 4(2): 465-70.

13. Igbeneghu OA, Lamikanra A. The bacteriological quality of different brands of bottled water available to consumers in Ile-Ife, south-western Nigeria. BMC research notes. 2014; 7(1): 859.

DOI: https://doi.org/10.1186/1756-0500-7-859 